\title{
PERCEIVED AND OBSERVED TEACHING CREATIVITY OF ENGLISH TEACHERS IN SMKN 1 NEGARA
}

\author{
Dwi Hendra Mahayana \\ English Language Education, Universitas Pendidikan Ganesha \\ e-mail: dwihendra.m@gmail.com \\ Luh Putu Artini \\ English Language Education, Universitas Pendidikan Ganesha \\ e-mail: putu.artini@undiksha.ac.id \\ Ni Nyoman Padmadewi \\ English Language Education, Universitas Pendidikan Ganesha \\ e-mail: nym.padmadewi@undiksha.ac.id
}

\begin{abstract}
Teachers' creativity is an important aspect that has an influential effect on students' competence, however research on this particular topic is hardly found. This study aimed at investigating teachers' creativity from two perspectives: From how they perceived and what they implemented in the classroom, and then to describe the discrepancy between the two Embedded mixed method was used as the design of this study which means the qualitative data was dominant than quantitative data QUAL (quan). Two EFL teachers of SMKN 1 Negara were chosen as the subject. Self-rated questionnaire, classroom observation sheet, and in-depth interview were used as the instruments. The discrepancy of two data were occurred. The investigation proves that the teachers rarely teach based on the lesson plan, teach inductively, conduct innovative learning by using technology as learning media. The teachers mainly focused on using same media in several meetings, conduct monotonous teaching activity.
\end{abstract}

Keywords: $21^{\text {st }}$ Century Learning, Teachers Creativity, Creativity

\section{INTRODUCTION}

In facing the globalization era, the people are prepared to ready follow the development of era. It starts from developing the human resource to able to solve complex problems related to life in a competitive and technology intensive world (Anagün, 2018). In this era, many changes occur in terms of social, economic and even education. The 21 st century become a popular term that usually appear in every aspects of life especially in education field. The term 21 st century began to emerge and was popular in the 1980s where governments, educators and large corporations in the United States began publishing reports containing educational trends and ways students and workers were prepared to be able to deal with the demands of a rapidly developing global economy, digital knowledge and society (Howard, 2018). Creativity and innovation are the key factors that lead to the industries successes in the competitive world. Thus, at that time new trend of education that have prepared were introduced in order to make human resource mastering the knowledge that required to succeed in 
work, life, citizenship, and ready to compete in this globalization era. The framework of 21 st century learning skills are communication, collaboration, critical thinking, creativity (Anjani et al., 2018). 21st Century learning skill expertise can be described as $4 \mathrm{c}$ and those four skills must really be mastered in this era of globalization. 21 st century skills require not only cognitive aspects but also affective and psychomotor aspects. Therefore, 21 st century education requires students to be able to compete and have competence so that they can develop reasoning, logical, systematic and critical thinking. The implementation of 21 st learning is identic with the use of technology in the learning process. 21st century learning and skills are considered as technology integration into teaching and learning which requires teachers to improve their technological knowledge as well as pedagogical knowledge and content knowledge (Bedir, 2019) In the 21st century technology has also been growing rapidly and requires human resources that can work with machines or various information and communication devices. (Deniz, 2018) stated that Adaptation from the 20th century to the 21st century can be a new challenge for people because 20th century skills are different from the 21 st century and new information and communication technologies have emerged and developed in the 20th century. The development of information and communication technology in this era encourages people to adjust themselves so that they are not excluded from this rapid development. However, each individual must also master skills that will not be done by machines or other electronic devices. Furthermore, the use of technology is required as the creative teacher in accommodating the 21st century learning (Henriksen et al., 2018).

Based on the challenge of 21st century learning, the school implements the 21st century learning which contains some skills and teaching pattern that related to current era. The current learning emphasized on the character education, which means the students not only mastering the material and the knowledge, but the students have to have good ability and good attitude as a modern human as well. Besides, the students are encouraged to not only master hard skills, but soft skills will also be an important part of competition in the world of work. The teachers have to involve technology in the learning process called IT-based learning. It will create a creative and innovative learning environment. The teacher could lead the students to use their own thinking to explore and figure out the material by themselves. It makes the students more active and directly involved to the learning process, therefore the students will easier to understand the material and mastering the knowledge. As we know, technology has been integrated to the education field. That was influenced by the development of globalization era that is known as 21 st century and Indonesia education field, K13 as a bridge to prepare the Indonesian students ready to face the challenge of the world. In K13, the learning process have to use technology in its implementation. Learning that uses technology is often referred to E-learning. By implementing E-learning that will use varieties of technology, the students will highly active and interesting to the learning process, therefore, the material will be understood easily. The students feel satisfied when they are taught through virtual learning as different aesthetic, the factors that influence is the interactive graphics, sound, and video deeply encourage the students into the learning (Al-Juda, 2017).

Learning process in promoting 21 st century learning requires well prepared planning for the its implementation. Various activities, medias and tools have to prepare to support students centered learning and also be able to create interesting and effective learning process. Besides that, the teacher should be able to motivate and organize the 
class that apply students centered learning especially in promoting 21 st century. All of those aspects are how the way the teacher prepares a good learning and it obviously needs a creativity from the teacher. In teaching in the class, the teacher should apply the creativity into the learning process in order to make the students could be creative as well (Stojanova 2010 in (Al-Dababneh \& E. K, 2017). Thus, the creativity of the teacher is very needed to engage students more take a role in a learning process. (Wibowo et al., 2018) explained that teacher creativity refers to several criteria. First, the teacher uses techniques, tools, creative material, learning methods that develop student creativity. Second, the teacher uses ways that make students think actively and creatively. Third, the teacher gives assignments to students that allow them to choose various strategies skillfully to solve problems, such as brainstorming, reflection, analysis, and causality. Fourth, the teacher always provides activities that train students to think creatively and imaginatively. Fifth, the teacher always gives students a situation where they can explore resources and ideas in an innovative way. Teaching creatively is about using imaginative approaches to make learning more interesting and effective whereas teaching for creativity refers to efforts put to develop learners' creative thinking (Cayirdag, 2017). Therefore, every effort that have done by the teacher to develop students' skills is belong to teacher's creativity. For example, teacher should prepare the material, medias, even her skill before teach in the class that use studentcentered learning. The teacher must develop his creativity to create good classes that implement student-centered students. The personal capacity of the teacher is very influential in developing his creativity. Teachers also have to explore their own potential in order to be able to express their creativity for classroom learning. In preparing every aspect that is required in learning process, every teacher has different ability to do that. According to Gardner in (Kinai, 2013) every creative individual is endowed with the ability to visualize, shape, and produce ideas themselves. Therefore, each individual has their own creativity in learning, especially in promoting $21 \mathrm{st}$ century learning. The teachers also have different level of creativity. It could be seen by taking a look to the perception of teacher about their own creativity. Based on (Dian \& Limantara, 2017) Perception is defined as thinking about various kinds of stimulus related to (color, aroma, sound, taste, feeling) captured by an individual to evaluate something. Therefore, the teachers' perception means the ability to see, hear, or become aware of something especially their creativity through the senses.

Several experts define teachers' creativity into several categories, namely producing a new and unique teaching method, variety strategies, and have strong commitments to promote learners' learning success through effective ways (Arifani, 2019). By preparing teaching creatively, instructors will enjoy more in teaching their students. That will directly give good effect to students and the classroom atmosphere will be conducive. The study that was conducted by (Kinai, 2013) aimed to figure out whether age, gender, and teaching experience influence the creativity of postgraduate student-teacher counselors. However, this study showed that age, gender and teaching experience did not have a significant effect on the teacher's creativity. It is influenced by other factors, such as divergent thinking, intelligence, and training.

Furthermore, the teachers' creativity is important thing to be involved in learning process. Therefore, the differences between how teachers perceive their creativity and how they implement it were crucial to investigate. The factors that create differences are very important to find out by interviewing the teacher. The results of the interview will reveal and clarify what factors actually affect the teachers' creativity so 
the discrepancy is arisen. Therefore, after carrying out the three processes, accurate data will be found about the actual creativity of the teacher.

\section{METHOD}

In this study, mix method was used with the embedded design. The Embedded design meant there was one data that would be dominant (Indrawan \& Yaniawati, 2016). The dominant data in this study were qualitative data. Thus, the quantitative data were less than qualitative data QUAL (quan). Additionally, quantitative data as supportive data that used to support the qualitative data as primary data in this embedded design (Creswell, 2012). The collected data in Self-rated questionnaire were in form of quantitative (number or scale) and the data were elaborated qualitatively. In classroom observation sheet, the data that collected were in form of quantitative and qualitative data because the researcher was allowed to add some notes about the findings while observing the teachers implement their creativity in English teaching. In obtaining the data in In-depth interview, audio recorder was used to record the researchers' confession about their creativity. All data that have been recorded were analyzed by using data reduction and changed into in form of script. This script was used to support all of findings that researcher found. This study was conducted in SMKN 1 Negara in 2019/2020 academic year, more specifically in second semester. SMKN 1 Negara was located on Jalan Tanjung No.Raya, Baler Bale Agung, Negara Sub-district, Jembrana Regency, Bali Province. SMKN 1 Negara was chosen as a setting of this study because this school belong to favorite vocational school in this Regency. Thus, the researcher wanted to conduct this study in this school in order to find out the teacher's creativity in the favorite vocational school in that Regency. Purposive sampling was used as sampling technique to obtain the object of this study. (Etikan et al., 2016) Stated that purposive sampling is one of the sampling that the researcher gains the subjects who are capable and willing to provide the information that are required in the study. The topic of this study was the creativity of EFL teachers, therefore the there are two teachers of SMKN 1 Negara became the object of the study.

The instrument used to collect the data were questionnaires and In-depth interview. This questionnaire was used in this study were self-rated and observation sheet questioners. The questionnaire was developed by relying on the creativity theory by (Boden, 1998) that stated there are 3 types of creativity that used to create new ideas namely combinational, exploratory and transformational creativity. Self-rated questionnaire was the first questionnaire that had purpose to discover the teacher perception about their creativity level in teaching English in the classroom. Through the self-rated questionnaire, the teacher answers all of the 24 statements about creativity. The teachers would also score their self in scale (1-5) and giving check list on that instrument based on their perception about their level of creativity. The explanation of level creativity has been described on the instrument as follows. Score 1 was reflected as unlikely creative means that the teachers never use new idea in the class and technology, score 2 was reflected as slightly creative means that the teachers rarely use new idea and technology, score 3 was reflected as moderately creative means that the teachers sometimes use new idea and technology, score 4 was reflected as creative means that the teachers often use new idea and technology and score 5 was reflected as very creative means that teachers always use new idea and technology in the class. Then, the teachers gave check list in which step they are being creative (Pre-activity, Whilst-activity, and Post-activity). There are information columns that can be filled by 
the teacher to add the comments and information about what things that make them become creative. If there are no statements that do not reflect teachers' creativity, the researcher had provided place for the teacher to write down their elements of creativity. Observation sheet was the second instrument that was used to observe the creativity of teachers in implementing the creativity in class. This instrument was used by the researcher, because this instrument was utilized to observe the implementation of teacher's creativity. This instrument contained same statements with the self-rated questionnaire. The researcher scored the level of teachers' creativity in scale (1-5). The detail meaning of every score of creativity is same as in the self-rated questionnaire. The researcher transcribed any additional information in information column. In-depth Interview was conducted after the discrepancy between the result in self-rated and observation sheet had been found. This interview was established to investigate the discrepancy of two data occur. Here the teachers were interviewed naturally by applying semi-structured interview. (O'Keeffe et al., 2016) assumed the way which are effective and efficient in gaining the expected is by conducting semi-structured interview. This semi-structured interview was used to make the teacher can maximize their confession and the researcher gets more accurate data.

The setting of the study was in a vocational school in a Regency. Therefore, the researcher conducted the observation before conducting the study in that school. This observation was aimed to recognize the school and to know how many English teachers in that school. The researcher was facilitated with permission letter that should be delivered to the school. The permission letter contained about the permission request to conduct this study in this school. After the permission letter was accepted and agreed, the researcher met the school's Head Master and The English Teachers of this school. The researcher conveyed the topic and what was needed in this study. The researcher also clarified the teachers that agree to be object of the study. To make researcher collect the data more easily, the researcher did discussion with the English Teacher about the technique of collecting the data and how the data would be collected. Therefore, the researcher could get the complete data.

There were two questionnaires have been used in this study. The Self-rated questionnaire became utilized by the teachers. Self-rated questionnaire was filled by the teacher about how they perceive their creativity in teaching English. This questionnaire was delivered to the teacher and they should answer 24 statements about creativity that were contained in the questionnaire. The teachers rated the level of their creativity by giving check list in the column based on the 1-5 scales. Furthermore, the classroom observation was aimed to discover the data about the implementation of teachers' creativity in the classroom. The classroom observation sheet was used by the researcher to discover the teachers' creativity level by observing how the teachers implement their creativity in real teaching, then determining in which level the teachers' creativity is. The researcher also gave checks list into the available column based on observation in the class. The questionnaire and observation sheet have same statements and criteria of creativity. In-depth Interview was conducted after the researcher discovered the discrepancy between self-rated questionnaire data and classroom observation sheet data. Thus, by using In-depth Interview, the obtained data were more natural and specific especially the researcher established semi-structured interview.

In this study, the obtained data were analyzed by observing the result of the instruments. On the self-rated questionnaire, the teacher assessed their creativity level by themselves. The questionnaire was designed by relying on the creativity theorist then 
it was specified into 12 indicators and manifested into 24 statements. The teacher gave check list in every column in each statements that was contained scale of creativity level. The teachers perceived in what level their creativity are by themselves. There were 24 statements about creativity on self-rated questionnaire. Those 24 statements were classified into three types of creativity. After that, the mean score in every type of creativity was calculated. The following formula demonstrates how to gain the mean score in every type of creativity.

$$
\text { Score (types of creativity) }=\frac{\text { Total of the mean score in every learning step }}{3}
$$

Furthermore, after the mean score in every type is found, those score was summed up then divided by three to reach the final score that reflected as the result of the score in self-rated questionnaire. The following demonstrates the formula used to calculate the final score in self-rated questionnaire.

After the data were collected, it meant the researcher had one data about the teacher's creativity in teaching English which was assessed by the teacher themselves. The result of this questionnaire were analyzed by detecting the point of each statements. The obtained data from the questionnaire were quantitative data. The score in every learning steps and 3 types of activity was classified into criteria of creativity. The criteria score of creativity was designed to interpret the creativity score. The following table indicates the criteria score of creativity.

Table 1. Criteria Used to Interpret Creativity Score

\begin{tabular}{|c|c|}
\hline Criteria of Creativity & Score \\
\hline Unlikely Creative & $1.00 \leq x \equiv 1.50$ \\
\hline Slightly Creative & $1.50<\frac{\text { se }}{2} 2.50$ \\
\hline Moderately Creative & $2.50<$ 害 3.50 \\
\hline Creative & $3.50<4.50$ \\
\hline Very Creative & $4.50<x$ \\
\hline
\end{tabular}

In classroom observation, the instrument facilitated the researcher to observe the teacher's creativity when the teacher implemented their creativity in the classroom. The teacher's creativity level was assessed by giving point in every statements that consist in the classroom observation sheet. Additionally, the notes and the pictures that was related to the teacher's creativity were interpreted by the researcher to support the data. Therefore, the data were in form of quantitative and qualitative. After the data was collected through classroom observation, the researcher had the second data related to the teachers' creativity implementation in the classroom. The result of this data were analyzed by looking at the point that were reached by the teacher on each 24 statements. The data in this observation also interpret the score into the criteria of creativity on table 1 to indicate the creativity level of the teachers. Through this instrument, the researcher has other data about teacher's creativity in implementing the English learning. Subsequently, the data from self-rated questionnaire and classroom observation were compared to find out the discrepancy between them. 
In-depth interview was used in interviewing the teacher in SMKN 1 Negara after the researcher found the different result of self-rated questionnaire and classroom observation sheet. The researcher conducted semi-structured interview model in order to make the result of the interview more natural and more specific. This process was carried out to determine the comprehension of the teachers related to the use of creativity in the learning process. After the data was collected through in-depth interviews, data reduction by Miles (1994) \& Faisal (2003) in (Sujarweni, 2014) was used to analyze the interview. The data in interview was changed from audio form into script form to facilitate the researcher in conducting the data reduction.

\section{FINDINGS AND DISCUSSION}

The aim of this study was to explore the discrepancy between teachers' perception toward their own creativity and the observed implementation of creativity in the real teaching in the class. Therefore, in this section the discrepancy that had found between teachers' perception and the observed implementation in the class were discussed. From the results of the questionnaire, the discrepancy between teachers' perception and the observed implementation in the classroom occurred.

This subsection presented the comparison between the score from teachers' perception and score in real implementation in the class. The following table presents the score in teachers' perception.

Table 2. Teachers' Perception

\begin{tabular}{llll}
\hline Number & Types of Creativity & $\begin{array}{l}\text { Score on Teachers' } \\
\text { Perception }\end{array}$ & Criteria \\
\hline 1 & Exploratory & 3.39 & Moderately Creative \\
2 & Transformational & 3.33 & Moderately Creative \\
3 & Combinational & 3.62 & Creative \\
Average & & 3.44 & Moderately Creative \\
\hline
\end{tabular}

Table presents, the teachers perceived themselves in moderately creative criteria in exploratory, moderately creative criteria in transformational and creative criteria in combinational creativity. The average score of three creativity showed that teachers perceived their creativity was moderately creative criteria. Subsequently, in general, they perceived themselves in the moderately creative criteria in creating various activity in the class, following the lesson plan, making group or work in pair, using inductive learning, integrating technology in delivering the material, using contextual problem, creating the students to solve their problem using their own prior knowledge, creating different media in every meeting, utilizing existed media in the class, creating attractive activity and combining online and offline platform in conveying the material, and, using conventional media when it is needed. The following table presents the overall score of teachers in every creativity. 
Table 3. Overall Findings on Observed Creativity

\begin{tabular}{llll}
\hline Number & Types of Creativity & $\begin{array}{l}\text { Score on Observation } \\
\text { on Teachers } \\
\text { Creativity }\end{array}$ & Criteria \\
\hline 1 & Exploratory & 2.04 & Slightly Creative \\
2 & Transformational & 1.86 & Slightly Creative \\
3 & Combinational & 1.66 & Slightly Creative \\
Average & & 1.85 & Slightly Creative \\
\hline
\end{tabular}

Table presents the detailed teachers' score in 3 creativity of creativity. The score was categorized the teachers in "Slightly Creative" criteria. Accordingly, the teachers were classified in "Slightly Creative" criteria due to they were rarely create and use various activities and medias in the class, the learning rarely followed the lesson plan, using inductive learning, integrating technology, using real problem, making the students solve their problem using their own prior knowledge, combining varies media such as modern media and conventional media, creating attractive activity and combining different medias in delivering the material.

Therefore, based on the here is different result between the teachers' perception and the observation. The teachers perceived their creativity in "Moderately Creative" in self-rated, however in implementing in the class, teachers were scored in "Slightly Creative" criteria through observation that was conducted.

The discrepancy occurred between how they perceived their creativity in teaching in the class and facts as observed in the real implementation of creativity in the classroom. On one side, the teachers perceived that they were moderately creative in implementing their creativity in the classroom. The teacher claimed that they sometimes teach based on the lesson plan, make the students work in group or in pair, teach inductively, use various activities and technology as learning media, conduct innovative learning by using combinational media, and modify the media and activities to be more interesting. In another side, the teachers mainly focused on using same media in several meetings, deductive learning, teacher center technique, monotonous teaching activity, one-way communication, rarely conducting innovative activity and integrating the contextual problem as learning material in the class. The teachers were focused on offline learning and printed media. Those happened due to several factors like the teacher need leisure time to create and prepare the media for teaching in some meetings and the ability of the teacher to know the proper media that students need during the learning process regarding the material would be taught. The teachers also inconsistent in implementing their creativity in every learning steps. Based on the obtained result, the teachers tended to implement their element of creativity in whilst activity when the students have more time to do the activities. The teachers consistently opened the class conventionally and did not apply their creativity. As in pre-activity, the teachers usually lack of time to do the activity that should be done in post-activity.

Additionally, based on the observation and the situation in real teaching in the class, the teachers were only capable in executing some of the creativity aspect of (Boden, 1998). The teachers utilize some technological-based learning media, sometimes teach conventionally, use offline learning wherein they used printed media and material, using same media in every meeting, conducting deductive learning. They also rarely in creating attractive activity in the class and modifying old media to be 
unique. Furthermore, they were also consistently inconsistent in implementing the creativity in the class. They were only capable applied their creativity mostly in whilstactivity. Thus, the different data were gained from those two data. The discrepancy occurred between those two data were elaborated by conducting interview to clarify the discrepancy that occurred. The result of the interview revealed that the teachers generally taught the students using conventional media since in their school, the facility was limited. The facilities of the school were intended for the laboratory or special room and not for the regular classroom. Consequently, they only taught the students through conventional media. They also preferred to teach the students through offline learning because they only used online learning as the media in delivering the assignment and the information. The teachers also acknowledged that they have limited time when preparing the medias and creative teaching because they have responsibilities as a teacher and housewife. The different stage of students cognitive also became the reason for the teacher to teach conventionally. The teachers also have little bit experience in using online and offline platform that usually have complex operational.

It could be assumed that the discrepancy between teachers' perception and facts as observed in the class had occurred due to the teachers rated themselves according to their subjective judgements. They felt creative when they use some medias in teaching, however, there were several elements of creativity that should be obeyed in being considered as creative one of them is the involvement of technology in teaching in accordance to promote 21st century learning. Additionally, based on finding of the study by (Fitrah, 2018) It stated the teachers have consciousness regarding to the importance of technology in creativity. The emerge of technology could help the teachers in exploring their creativity and encourages learners' creativity. It related to the challenge of 21 st Century era that require the learners master some skills and think creatively through the involvement of technology in teaching. In a fact, the teacher as supervisor in the class realize that the utilize of technology in teaching could increase the creativity of the teacher in the class that would give effect to the students' achievement in learning. Moreover, related to the theory of (Kinai, 2013) she stated that enlargement of creativity of teachers is not depend on their age, gender, and teaching experience bur there are factors, such as different thinking, intelligence, and training. Therefore, it could be argued that ability in preparing proper media and activity, the different thinking of teacher, intelligence, and training become the factors of why the teachers in SMKN 1 Negara were scored as slightly creative.

\section{CONCLUSION AND SUGGESTION}

English teachers in SMKN 1 Negara perceived themselves as moderately creative in teaching English in the classroom. They also inconsistent in implementing creative activity in every learning step. English teachers in SMKN 1 Negara were considered as slightly creative in implementing the creativity in real teaching. They were also scored that they were consistently consistent in implementing creative activity in every learning activity. The discrepancy between teachers' perception and facts as observed in teaching creativity in the class were found. In accordance with the results and discussion, the conclusion could be taken that, there was discrepancy between perception of the teacher and the implementation in real class. It could be happened because the subjective judgement of the teachers about themselves that made in perceiving themselves the teachers rated themselves in moderately creative. However, the teachers SMKN 1 Negara were scored as slightly creative based on the observation 
in real teaching. Interviews were established naturally in order to obtain oriental data. In the interview, it was revealed that most of the teachers focused on using only a few media, learning that tends to be deductive, students-centered learning, monotonous learning activities at each meeting, using the same media in every meeting, rarely creating innovation, rarely giving problems that contextual to improve student cognitive. Teachers tended to use offline media instead of online media. Teachers rarely modify the media and activities to be more interesting. Basically, all individuals have creativity. However, every individual has a different level of creativity. The teachers know that they have their own views about their creativity. How they perceive their creativity will not necessarily be the same as how they implement it directly into the classroom.

Moreover, based on the study that had been done. There are suggestions that the researchers want to share to the associated parties. The first is for teachers, the teachers are suggested to implement their creativity in real teaching as they perceived their own creativity. They are expected to develop their own creativity that reflected as $21 \mathrm{st}$ century learning that require the student-centered learning and the use of technological based media. Teachers also should have right concept about the creativity in order to make the teachers could implement the creativity properly according to the element of creativity. The intelligence of the teacher is required when the teachers want to apply their creativity in teaching whether it would be applied in a learning media or in teaching method. The teachers also could join a training of how to explore their creativity in teaching especially in utilizing the exist technology. The second is for the school, the school are suggested to support the development of teachers' creativity by introducing and providing the newly media that is needed by teacher as requirement in establishing 21st century learning. The school is also expected to give training about how to implement the creativity in teaching in the classroom. The last suggestion is directed for other researchers, the scope of present study was limited on identifying teachers' perception and observing the real implementation about their teaching creativity in SMK Negeri 1 Negara. Thus, the other researchers are suggested to investigate deeper about other variables that related to the teachers' creativity in further study.

\section{REFERENCES}

Al-Dababneh, \& E. K, A.-Z. (2017). Can Teachers' Self-reported Characteristics and Beliefs about Creativity Predict Their Perception of Their Creativity Practices in the Classroom? International Journal Of Special Education, 32(4), 723-745. https://files.eric.ed.gov/fulltext/EJ1184189.pdf

Al-Juda, M. Q. . (2017). Distance Learning Students' Evaluation of E-Learning System in University of Tabuk, Saudi Arabia. Journal of Education and Learning, 6(4), 324-335. https://doi.org/10.5539/jel.v6n4p324

Anagün, Ş. S. (2018). Teachers ' Perceptions about the Relationship between 21st Century Skills and Managing Constructivist Learning Environments. International Journal of Instruction, 11(4), 825-840.

Anjani, D., Maridi, \& Suciati. (2018). Inquiry Based Learning Module to Empower Cooperation Skills. Journal of Education and Learning (EduLearn), 12(2), 172178. https://doi.org/10.11591/edulearn.v12i2.8268

Arifani, Y. (2019). The Influence of Male and Female ESP Teachers' Creativity toward Learners' Involvement. International Journal of Instruction, 12(1), 237-250. 
Bedir, H. (2019). Pre-service ELT teachers' beliefs and perceptions on 21st century learning and innovation skills (4Cs). Journal of Language and Linguistic Studies, 15(1), 231-246. https://doi.org/10.17263/jlls.547718

Boden, M. A. (1998). Creativity and Artificial Intelligence. Artificial Intelligence, 103, $347-356$.

Cayirdag, N. (2017). Creativity Fostering Teaching:Impact of Creative Self-efficacy and Teacher Efficacy. Kuram Ve Uygulamada Ĕ̈itim Bilimleri Educational Sciences, 1959-1975. https://doi.org/10.12738/estp.2017.6.0437

Creswell, J. (2012). Planning, Conducting and Evaluating Quantitative and Qualitative Researc. Pearson Education. http://basu.nahad.ir/uploads/creswell.pdf

Deniz, C. T. (2018). Pre-service Teachers' Opinions about the Use of 21st Century Learner and21st Century Teacher Skills. European Journal of Educational Research, 8(1), 181-197. https://doi.org/10.12973/eu-jer.8.1.181

Dian, Y., \& Limantara, P. (2017). Pengaruh Customer Perception Terhadap Minat Beli Konsumen Melalui Multiattribute Attitude Mode pada Produk Makanan Organik. Jurnal Manajemen Pemasaran, 11(2), 69-77. https://doi.org/10.9744/pemasaran.11.2.69

Etikan, I., Musa, S. A., \& Alkassim, R. S. (2016). Comparison of Convenience Sampling and Purposive Sampling Comparison of Convenience Sampling and Purposive Sampling. American Journal of Theoretical and Applied Statistics, 5(1). https://doi.org/10.11648/j.ajtas.20160501.11

Fitrah. (2018). The Role of Technology in Teachers' Creativity Development in English Teaching Practices. TEFLIN Journal, 29(2), 177-193. https://doi.org/http://dx.doi.org/10.15639/teflinjournal.v29i2/177-193

Henriksen, D., Henderson, M., Creely, E., Ceretkova, S., Černochová, M., \& Sendova, E. (2018). Creativity and Technology in Education: An International Perspective. Technology, Knowledge and Learning, December. https://doi.org/https://doi.org/10.1007/s10758-018-9380-1

Howard, P. G. (2018). Twenty-first century learning as a radical re-thinking of education in the service of life. Education Sciences, 8(4). https://doi.org/10.3390/educsci8040189

Indrawan, R., \& Yaniawati, P. (2016). Metodologi Penelitian Kuantitatif, Kualitatif dan Campuran untuk Manajemen Pembangunan dan Pendidikan. PT Refika Aditama.

Kinai, T. (2013). Kenyan Student-Teacher Counsellors' Creativity and Its Relationship with Their Gender, Age, and Teaching Experience. Online Submission, 3(5), 296304.

O'Keeffe, J., Buytaert, W., Mijic, A., B. N., \& Sinha, R. (2016). The use of Semistructured Interviews for the Characterisation of Farmer Irrigation Practices. Hydrolody and Earth System Sciences, 1911-1924. https://doi.org/10.5194/hess20-1911-2016

Sujarweni, W. V. (2014). Metode Penelitian: Lengkap, Praktis dan Mudah Dipahami. PUSTAKABARUPRESS.

Wibowo, A., Saptono, A., \& Suparno. (2018). Does Teachers' Creativity Impact On Vocational Students' Entrepreneurial Intention? Journal of Entrepreneurship Education, 21(3). 